\title{
Non-Commercial Sources
}

National Cancer Institute

\section{Source}

National Cancer Institute. Non-Commercial Sources. NCI Thesaurus. Code C19288.

A category used for classifying sources of research reagents obtained through academic institutions. 